\begin{tabular}{|c|c|c|}
\hline \multirow{3}{*}{$\begin{array}{l}\text { BENTHAM OPEN } \\
\text { CrossMark }\end{array}$} & $\begin{array}{c}\text { The Open Construction and Building } \\
\text { Technology Journal }\end{array}$ & $\begin{array}{l}\text { The Open } \\
\text { Construction \& Building } \\
\text { Technology lournal }\end{array}$ \\
\hline & Content list available at: www.benthamopen.com/ТОВСТJ/ & \\
\hline & DOI: $10.2174 / 1874836801711010371$ & \\
\hline
\end{tabular}

RESEARCH ARTICLE

\title{
Environmental Improvement in Use of Fine Fraction Recycled Aggregates as a Raw Material in Masonry Mortar Fabrication
}

\author{
Mariano González Cortina ${ }^{1, *}$, Pablo Saiz Martínez ${ }^{1}$ and Francisco Fernández Martínez ${ }^{2}$ \\ ${ }^{I}$ Architectural Construction and Control Department, Higher Technical School of Building Construction, Universidad \\ Politecnica de Madrid, España \\ ${ }^{2}$ Chemistry and Polymers Department, University school of Technical Industrial Engineering, Technical Universidad \\ Politecnica de Madrid, España
}

Received: June 05, 2017

Revised: July 2, 2017

Accepted: July 3, 2017

\begin{abstract}
:
Background:

Great use of raw material and natural resources as well as generation of huge amount of waste make the construction and building sector one of the less sustainable human activities.

\section{Objective:}

The main aim of this research is to study both technical feasibility and environmental sustainability of fine fraction recycled aggregates (RA) use in masonry mortar fabrication. Method. The tests were developed using the binder CEM IV/B (V) $32.5 \mathrm{~N}$ and two types of RA: ceramic RA and concrete RA. The substitution percentages were $50 \%, 75 \%$ and $100 \%$ and cement-to-aggregate by dry weight proportions were $1: 3$ and 1:4.
\end{abstract}

\section{Results:}

Performed tests show that cement-based mortars fabricated with CEM IV/B (V) $32.5 \mathrm{~N}$ can incorporate concrete and ceramic recycled aggregates, using both cement-to-aggregate proportions, complying with the limits established by the Spanish standards. On the other hand, carbon footprint calculation of one of the RA used in the research and a comparative study with natural aggregate (NA) carbon footprint were carried out to analyze environmental sustainability of fine fraction RA. Conclusion. The results show that the amount of $\mathrm{kgC}_{\mathrm{o} 2}$ eq released into the atmosphere as a result of RA fabrication is significantly lower compared with the emissions from NA fabrication, and therefore the use of this type of waste reduces greenhouse gas emissions.

Keywords: Waste treatment, Fine recycled aggregate, Recycled mortar characterization, Carbon footprint.

\section{INTRODUCTION}

Construction and Demolition Waste (CDW) raises an environmental problem due to the lack of prevention in its production process and the little use of recycled material. According to the European Commission DG ENV [1], 461 millions of tons of CDW is produced in Europe per year. The percentages of recycling and reuse of CDW is very different for different countries of Europe. For example in Spain only 14\% of CDW is being recycled and reused, this rate is too low as compared to the average recycling rate in Europe which is about $50 \%$ [2]. In order to improve this situation, in the year 2008 the new legislation on the CDW [3] come into force, fostering the recovery of waste at its end-of-life and incorporating a study on CDW management during the planning process and a plan on CDW management during the construction phase.

\footnotetext{
${ }^{*}$ Address correspondence to this author at Higher Technical School of Building Construction, Madrid Polytechnic University, Juan de Herrera 6, 28040 Madrid, Spain, Tel: +34913367596; E-mail: mariano.gonzalezc@upm.es
} 
Regarding the use if the CDW, presently in Spain it is used mainly as packing for highways stretches and, to a lesser extent, in concrete fabrication. Derived from the researches carried out in Spain [4], the current Structural Concrete Code [5] includes a part related to the recycled aggregates which recommend to substitute $20 \%$ of natural aggregates with this type of material.

In spite of the current legislation, Spanish market continues not to include definitively the use of recycled aggregates into the construction process. The reason is on one side the low cost of natural aggregates because of the deep crisis of Spanish construction sector, and on the other hand, the lower quality of RA compared to natural aggregates.

A recent research carried out in Spain classifies recycled aggregates according to the compounds they are formed of: concrete RA, mixed RA and ceramic RA, depending on the material that predominates in each fraction [6].

Physical, chemical and mechanical characteristics of RA are determined mainly by pollutant and impurity content and adhered mortar content [7], [8], in fact, adhered mortar content of RA is the main difference regarding the natural aggregates. As it was demonstrated by diverse researches that, adhered mortar leads to the lower density and higher absorption of recycled aggregates, which is the determinant characteristic that decreases the mechanical behaviour of mortars fabricated with RA [7], [9], [10]. Moreover, this characteristic of RA is more pronounced in smaller fractions presenting poorer behaviour compared to coarse fraction aggregates [8]. Other factor that impacts directly the quality of RA is the process of fabrication. The main properties of RA vary according to a fabrication process carried out by a treatment plants [7], [11], [12] and of course they depend on the source material [13].

Various scientific researches have studied the feasibility of incorporating fine fraction of RA in masonry mortars production. According to the consulted bibliography, the optimal substitution percentage varies significantly from one author to another, mainly due to great variability of these materials. For example, Seung-Tae Lee [14] studied the influence of RA emerging from demolition of concrete structures, using mortar sample in the presence of magnesium sulphate. The substitution of NA with RA is carried out using the following percentages: $0 \%, 25 \%, 50 \%$ and $100 \%$, being the mortar samples with magnesium sulphate exposed to ambient temperature during one year. The obtained results show that substituting up to $50 \%$ of natural aggregates, the mortars withstand harsh environment in the presence of magnesium sulphate, and water absorption increases using higher substitution percentages.

Silva, J et al. [15] studied the feasibility of incorporation of ceramic RA in masonry mortar fabrication process. The obtained results proved that at least $20 \%$ of this type of material can be used in masonry mortar fabrication.

Braga, M. et al. [16] studied the behaviour of recycled mortars after incorporating very fine fraction concrete recycled aggregates. Substituting $15 \%$ of natural aggregates, improvement of compressive and bond strength could be observed. Other properties however showed poor performance in recycled mortars (water vapour permeability, elasticity modulus, water absorption by capillarity). Thus, the use of $15 \%$ of RA improves some properties of mortars compared to conventional mortars.

Fernandez et al. [17] evaluated the possibility to incorporate fine fraction of RA in masonry mortars using CEM II/BL $32.5 \mathrm{~N}$. The obtained results show that the replacement ratio of $50 \%$ can be achieved in mortar for indoor use.

The main aim of this work is the evaluation of recycled mortars properties both in fresh and hardened state using different replacement percentages of natural sand with three types of RA coming from collaborating recycling plant. Furthermore, this research includes an environmental study of recycled aggregated fabrication, and a comparison with the fabrication of natural aggregates. The results of this study present a contribution regarding the published works, and could help to increase CDW recycling rates.

\section{MATERIALS AND METHODS}

\subsection{Materials}

In this research, such basic materials usually used for cement mortars fabrication as cement, aggregate and water were used. Moreover, it was necessary to use the additive Glenium SKY 604 to obtain a proper consistency of recycled mortars, due to the high water demand of recycled aggregate compared with natural sand.

The binder used in the study was CEM IV/B (V) $32.5 \mathrm{~N}$, suitable for mortar production and for masonry in general. The properties of this cement are specified by Spanish and European standard UNE-EN 197-1. The main characteristics are shown in (Table 1). 
Table 1. Characteristics CEM IV/B (V) 32.5 N.

\begin{tabular}{|c|c|}
\hline \multicolumn{2}{|c|}{ Physical characteristics } \\
\hline Density (g/cm3) & 2.85 \\
\hline Blaine specific area $\left(\mathrm{cm}^{2} / \mathrm{g}\right)$ & 4400 \\
\hline Initial set (min) & 230 \\
\hline Final set (min) & 285 \\
\hline \multicolumn{2}{|c|}{ Chemical characteristics } \\
\hline Elements & Result (\%) \\
\hline $\mathrm{Al}_{2} \mathrm{O} 3$ & 13.40 \\
\hline $\mathrm{CaO}$ & 35.55 \\
\hline $\mathrm{Fe}_{2} \mathrm{O} 3$ & 3.50 \\
\hline $\mathrm{K}_{2} \mathrm{O}$ & 1.80 \\
\hline $\mathrm{MgO}$ & 2.60 \\
\hline $\mathrm{SiO}_{2}$ & 31.90 \\
\hline $\mathrm{TiO}_{2}$ & 0.60 \\
\hline $\mathrm{MnO}$ & 0.05 \\
\hline $\mathrm{P}_{2} \mathrm{O} 5$ & 0.33 \\
\hline $\mathrm{NaO}_{2}$ & 0.02 \\
\hline Loss on ignition & 8.65 \\
\hline
\end{tabular}

Aggregates used for reference mortars fabrication were provided by the Cemex Company. Integrated CDW Treatment Plant of Madrid Region "El Molar" provided the research with recycled aggregates. Two different samples of RA were employed: fine recycled aggregates RA-1 and RA-2 originating from the ceramic recycling process and concrete recycling process, respectively.

Recycled mortars were prepared using the superplasticizer additive Glenium Sky 604 by BASF Company. This is a high-activity water reducing/superplasticising additive based on polycarboxylates.

Glenium SKY 604 was prescribed by BASF Company technical department to improve consistency of recycled mortars.

\subsection{Test Methodology}

With the aim of characterization of RA used in this research and studying the technical and environmental feasibility of their incorporation in masonry mortars, the following testing program has been established:

In the first part, the following tests were carried out for the characterization of recycled aggregates used in this research: particle size distribution curve, fines content, fineness modulus, relative and bulk density, absorption and Xray diffraction. To elaborate mixes for this research, dosages shown in Table (2) were used. All the mixes were fabricated to obtain plastic consistency between 175 $\pm 10 \mathrm{~cm}$ (UNE-EN 1015-3).

Table 2. Dosages.

\begin{tabular}{|c|c|c|c|c|c|c|}
\hline \multicolumn{9}{|c|}{ Dosage } \\
\hline Type & \multicolumn{3}{|c|}{ Dosage 1:3 c/a } & \multicolumn{3}{c|}{ Dosage 1:4 c/a } \\
\hline & $\mathbf{5 0 \%}$ & $\mathbf{7 5 \%}$ & $\mathbf{1 0 0 \%}$ & $\mathbf{5 0 \%}$ & $\mathbf{7 5 \%}$ & $\mathbf{1 0 0 \%}$ \\
\hline RA-1 & 0.58 & 0.66 & 0.70 & 0.75 & 0.86 & 0.90 \\
\hline RA-2 & 0.58 & 0.66 & 0.70 & 0.75 & 0.86 & 0.90 \\
\hline NA & - & - & 0.55 & - & - & 0.62 \\
\hline
\end{tabular}

Note: $1 \%$ of additive over the weight of cement

Compressive and flexural strength were analyzed using prismatic specimens of $40 \times 40 \times 160 \mathrm{~mm}$, being cast and cured in a humid chamber at $20^{\circ} \mathrm{C}$. Flexural and compressive strength were determined following the technical prescription of the UNE-EN-1015-11 standard.

In the second part, the possibility of RA incorporation in masonry mortar fabrication was studied. To this end, one type of binder was used: CEM IV/B (V) $32.5 \mathrm{~N}$. There were suggested three substitution percentages to replace natural sand with two types of recycled aggregates: $50 \%, 75 \%$ and $100 \%$, and cement-to-aggregate by dry weight proportions 
were 1:3 and 1:4. Recycled aggregates obtained from treatment plants were sieved in the laboratory, eliminating material retained on the $4 \mathrm{~mm}$ sieve and material passed through $0.063 \mathrm{~mm}$ sieve, because of poorer characteristics of aggregates of this fraction.

The following code was employed for the mixes identification:

RA-N $-\mathrm{X}$

Where $\mathrm{RA}=$ Recycled aggregates,

$\mathrm{N}^{\mathrm{o}}=$ Recycled aggregate type $(1=$ ceramic recycled aggregate and $2=$ concrete recycled aggregate $)$,

$\mathrm{X} \%=$ Recycled aggregates substitution percentage.

In the third part, ceramic recycled aggregate carbon footprint was measured keeping in view the environmental feasibility of this material. This study was based on the standard UNE-EN 15804 collaborating with the company responsible for the CDW management and for RA fabrication which is called TECNOLOGIA Y RECICLADO S.L. (TECHNOLOGY AND RECYCLING L.S.)

\section{EXPERIMENTAL RESULTS AND DISCUSSION}

\subsection{Characterization of Aggregates}

Characterization of fine recycled aggregates samples was based on the technical requirements regulated by the standard UNE-EN-13139: “Aggregates for mortar". The results of physical characterization of recycled aggregates are presented in (Table 3).

Table 3. Aggregates characteristics.

\begin{tabular}{|c|c|c|c|c|}
\hline \multicolumn{5}{|c|}{ Fine Recycled Aggregates Characteristics } \\
\hline Test & Standard & RA 1 & RA 2 & NA \\
\hline Fine Content $(\%)$ & UNE-EN-933-1 & 4.12 & 4.15 & 2.13 \\
\hline Fineness Modulus (\%) & UNE-EN-13139 & 4.47 & 4.27 & 4.23 \\
\hline Bulk Dens. $\left(\mathrm{kg} / \mathrm{m}^{3}\right)$ & UNE-EN-1097-3 & 1277 & 1320 & 1540 \\
\hline (Relative Dens. $\left(\mathrm{kg} / \mathrm{m}^{3}\right)$ & UNE-EN-1097-6 & 2130 & 2150 & 2430 \\
\hline Water absorption (\%) & UNE-EN-1097-6 & 7.55 & 5.16 & 0.95 \\
\hline
\end{tabular}

As it can be observed from the results presented in Table (3), the main difference of recycled aggregates compared with natural sand is their high absorption and lower density. As the result of this high absorption, recycled mortars need significantly bigger quantity of water for mixes elaboration, what negatively affects their mechanical properties.

Recent researches carried out in Spain [6] conclude that there are no pure RA, considering concrete RA as an aggregate that contains at least $90 \%$ of this material. In case of ceramic RA, there is an established minimum percentage of $60 \%$. For this reason, the rest of the physical characteristics, with the exception of absorption, show similar results for both types of studied recycled aggregates.

Fig. (1) shows particle size distribution curve analysis of different types of aggregates used in the research according to the requirements established by the UNE-EN-933-2 and the UNE-EN-933-1. As it can be observed in Fig. (1), RA present continuous size distribution curve which is an important characteristic for the elaboration of masonry mortars as it facilitates a good consistency of this material [7].

Below, in Table (4) the results obtained in the X-ray diffraction test are shown.

Table 4. X-Ray Diffraction.

\begin{tabular}{|c|c|c|}
\hline Mineral Phase & Mineral Relative Abundance \\
\hline & RA 1 & RA 2 \\
\hline Calcite & $* * * * * *$ \\
\hline Gypsum & $* *$ & $*$ \\
\hline Phologopite & $* * * *$ & $*$ \\
\hline Quartz & $* * *$ & $* * *$ \\
\hline Sanidine & $* *$ \\
\hline
\end{tabular}

Note: The results correspond to the average of 6 samples taken from every type of RA. 
X-ray diffraction pattern was measured using the Cu-Ka radiation ( 1 1 $1 / 4$ 1.540598 $\AA$ ) with a Siemens D500 diffractometer equipped with a graphite monochromator. Data were collected at $300 \mathrm{~K}$ over an angular range of $10^{\circ}<$ $2 \theta<110^{\circ}$ by scanning in steps of $0.05^{\circ}$ and counting times of $10 \mathrm{s.} 40 \mathrm{kV}$ voltage and $20 \mathrm{~mA}$ current were used.

As it can be observed in the Table (3), the principle and more crystalline founded phases are quartz and calcite. Other obtained phases, such as gypsum, phlogopite and sanidine do not show high crystalline behaviour and show low intensities in the carried out tests.

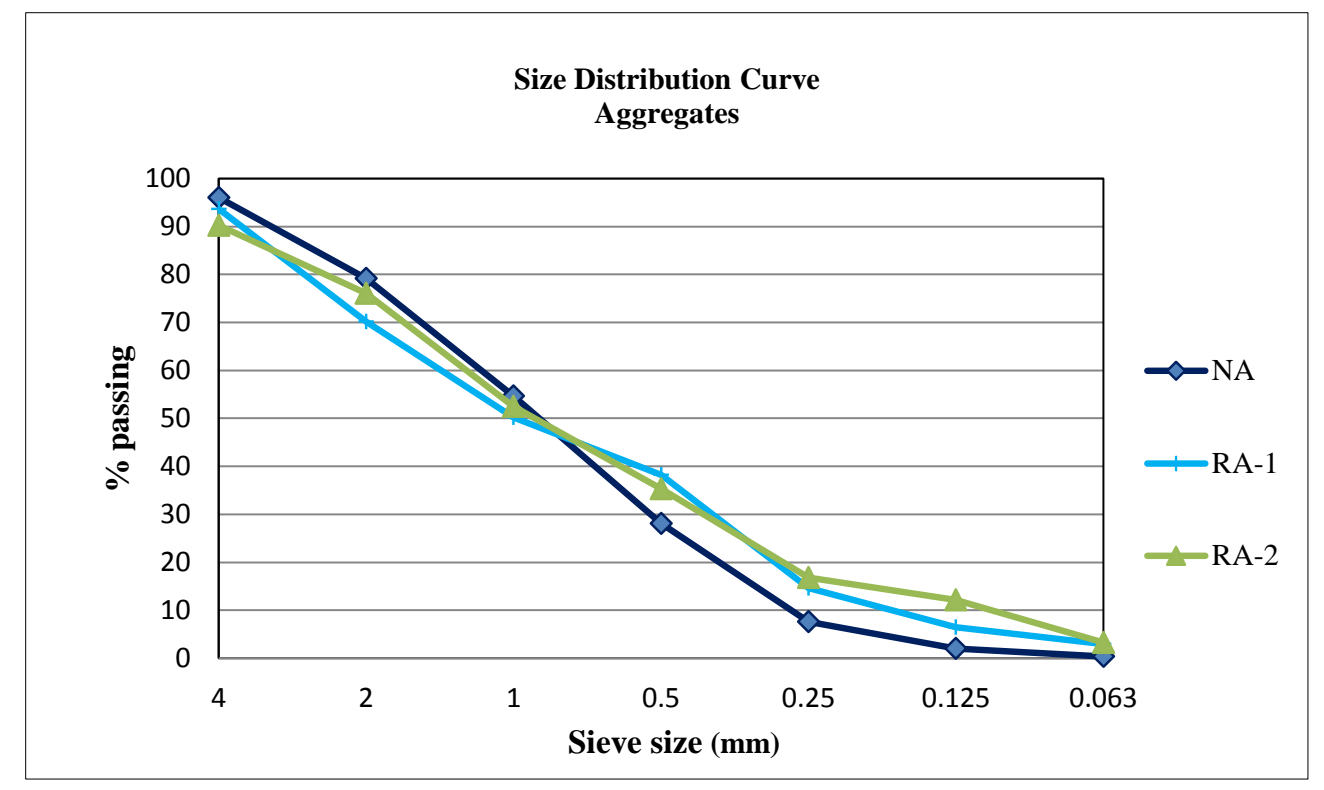

Fig. (1). Size Distribution Curve of aggregates.

\subsection{Recycled Mortar Characterization}

Characterization of recycled mortars was divided in two phases. During the first phase flexural and compressive strength tests were carried out using two dosages and three substitution percentages described in the Methodology.

During the second phase the characterization of recycled mortars was completed carrying out the tests of density, bond strength, shrinkage, absorption by capillarity and water vapour permeability for the mixes that gave the best results in the first phase.

\subsubsection{Phase 1}

Table (5) shows the results obtained in the tests of flexural and compressive strength.

Table 5. Flexural and compressive strength test.

\begin{tabular}{|c|c|c|c|c|c|c|c|}
\hline \multirow{2}{*}{\begin{tabular}{|}
\multirow{2}{*}{ Recycled mortar } \\
\cline { 3 - 8 }
\end{tabular}} & \multicolumn{3}{|c|}{ Dosage } \\
\hline \multirow{2}{*}{ RA Type } & Test(MPa) & $50 \%$ & $75 \%$ & $100 \%$ & $50 \%$ & $75 \%$ & $100 \%$ \\
\hline \multirow{2}{*}{ RA 1 } & Flexural & 5.13 & 4.77 & 4.02 & 3.47 & 3.24 & 3.02 \\
\cline { 2 - 8 } & Compressive & 17.62 & 15.44 & 14.70 & 12.51 & 10.11 & 9.23 \\
\hline \multirow{2}{*}{ RA 2 } & Flexural & 5.44 & 5.12 & 4.78 & 3.78 & 3.21 & 3.27 \\
\cline { 2 - 9 } & Compressive & 20.34 & 17.86 & 15.23 & 12.67 & 11.91 & 10.42 \\
\hline \multirow{2}{*}{ NA } & Flexural & - & - & 5.74 & - & - & 4.12 \\
\cline { 2 - 8 } & Compressive & - & - & 23.11 & - & - & 17.52 \\
\hline
\end{tabular}

In all the studied dosages it can be observed that compressive and flexural strength lowers with the increase of RA incorporation rate, observing the most significant decrease in the mixes with 100\% of RA and 1:4 cement-to-aggregate proportion, as expected. In all the studied mixes, the obtained compressive strength values comply with the limits required for the class M 7,5 MPa established by the standard UNE-EN 998-1. As a result, these recycled mortars elaborated with $100 \%$ of RA are valided to be used as masonry mortars after analyzing this property. Regarding the 
flexural strength, masonry mortars do not have to comply with any minimum value, thus the obtained results are accepted as valid.

\subsubsection{Phase 2}

Table (6) shows the rest of the tests carried out with recycled mortar fabricated with 100\% of RA using 1:4 dosage which completes the characterization of recycled mortar.

Table 6. Recycled mortars characterization.

\begin{tabular}{|c|c|c|c|}
\hline \multirow{2}{*}{ Test } & \multicolumn{3}{|c|}{ RA Type } \\
\cline { 2 - 4 } & RA 1 & RA 2 & NA \\
\hline Wet density $(\mathrm{gr} / \mathrm{cm} 3)$ & 2.09 & 2.13 & 2.18 \\
\hline Dry density $(\mathrm{gr} / \mathrm{cm} 3)$ & 1.73 & 1.79 & 1.97 \\
\hline Real density $(\mathrm{gr} / \mathrm{cm} 3)$ & 2.10 & 2.12 & 2.26 \\
\hline Bond strength $(\mathrm{N} / \mathrm{mm} 2)$ & 0.42 & 0.40 & 0.51 \\
\hline Shrinkage $(\mathrm{mm} / \mathrm{m})$ & 0.112 & 0.096 & 0.031 \\
\hline Water abs. capillarity $(\mathrm{kg} / \mathrm{m} 2 * \mathrm{~min} 0.5)$ & 0.77 & 0.69 & 0.60 \\
\hline $\begin{array}{c}\text { Water vapour permeability } \\
\text { (kg/m.s.Pa) }\end{array}$ & $5.61^{-12}$ & $6.44^{-12}$ & $3.09^{-12}$ \\
\hline
\end{tabular}

Both dry density and real density (UNE-EN 1015-10) depend on the density of compound materials, particle size distribution and water-to-cement proportion. Generally, dry density and real density are lower in recycled mortar as compared to mortars fabricated using natural sand and it has repercussion on the mechanical properties of recycled mortar because of its higher porosity.

Results of bond strength test (UNE-EN 1015-2) and shrinkage test (measurements taken during 72 hours) show worse behavior of recycled mortars as compared to the reference ones. Bond strength, among other factors, is a consequence of formation of crystals produced by binder hydration. In any case, obtained values are higher than the limit of $0.30 \mathrm{~N} / \mathrm{mm} 2$ established by the UNE-EN-998-1 standard for this type of mortar.

As it can be seen in Table (6), water vapor permeability values for mixes containing RA are higher compared to mixes elaborated with natural sand (UNE-EN 1015-19). This characteristic enables the evacuation of water vapor existing inside a building avoiding in this way the condensation in internal enclosure walls layers.

Regarding absorption by capillarity (UNE-EN 1015-18), mortars fabricated using recycled aggregates show values that are significantly higher than those of conventional mortars. This occurs due to the higher absorption of recycled aggregates that leads to the fabrication of mortars with less density and porous, facilitating the circulation of water in the sample capillaries.

\subsection{Carbon Footprint}

This part is dedicated to the calculation of carbon footprint associated with the fabrication of ceramic recycled aggregates in the plant of waste integral management TEC-REC situated in the Community of Madrid. The results obtained for this type of recycled aggregate can be also valid for concrete recycled aggregate as both types of aggregates undergo the same processes in the waste treatment plant.

The reference standard used for the calculation is UNE-EN ISO 14040, which specifies the stages of the study: 1Definition of objectives and scope, 2- general analysis of inventory, 3- impact evaluation and 4- objectives interpretation.

The standard UNE-EN 15804 "Sustainability in Construction" was also used for the calculation. This standard provides with the structure that guarantees that all the Environmental Product Declarations (EPD) of the construction products are obtained, verified and presented in a harmonized manner. Calculation of carbon footprint of recycled aggregates is focused on the information modules $\mathrm{C} 1-\mathrm{C} 4$ that correspond to the end of life stage.

\subsection{Carbon Footprint Calculation}

The functional unit taken as a reference was $1 \mathrm{~kg}$ of ceramic RA. Regarding the limits of the established system, the study of carbon footprint of ceramic RA is focused on the stage C3 (waste treatment) that corresponds to the end of life stage. The study embraces those processes that are performed in the waste center, from the reception of the material 
from the construction and demolition works to the point when the product is valid to be placed on the market.

Fig. (2) shows the general scheme of recycling plant and different processes that recycled aggregates undergoing prior to sale. To simplify the scheme, different materials that are obtained in the plant are grouped into processes and only those relevant to ceramic recycled aggregates fabrication are shown.

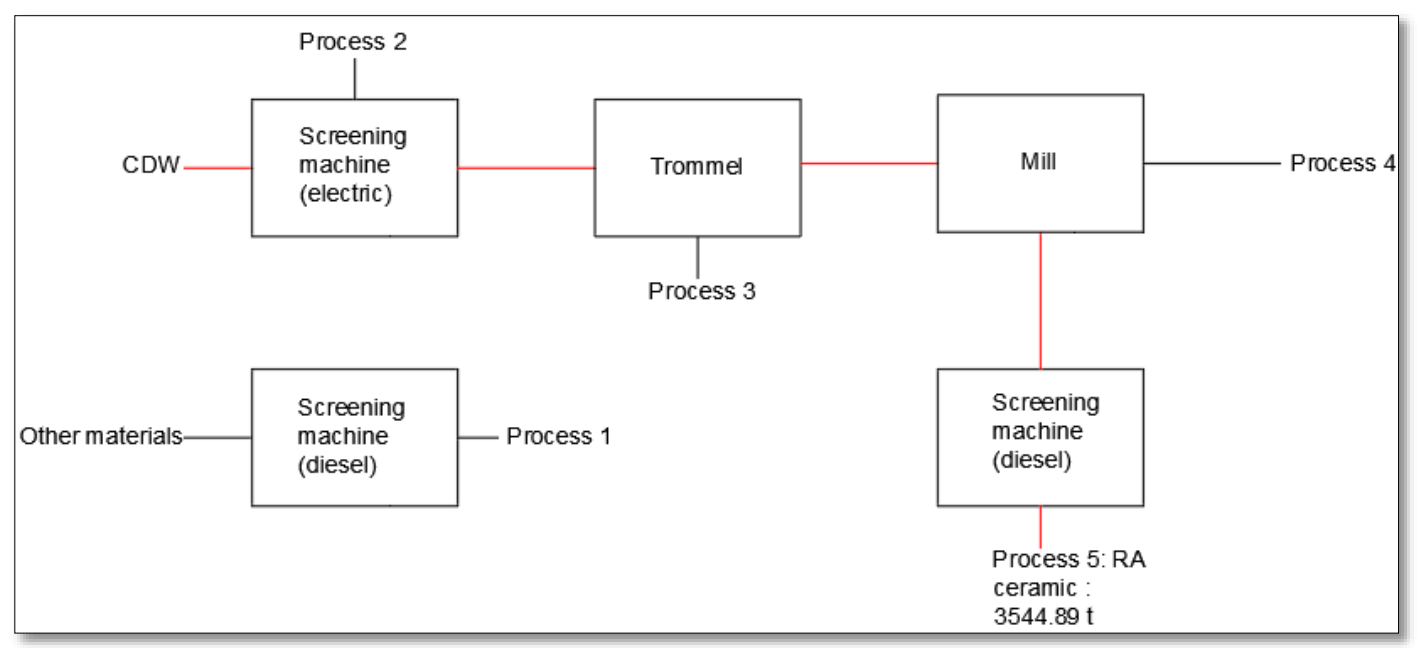

Fig (2). General scheme of recycling plant.

Once the different processes performed in the recycling plant are explained, it is necessary to know the energy consumption associated with each one of them to be able to classify that determined percentage of electricity and total diesel oil consumption are attributable to each resultant material.

Assignment of light and diesel to each material obtained in the plant was carried out in the following way: The consumption of $\mathrm{kW}$ and diesel oil was distributed in each of the processes depending on the machinery involved and was distributed proportionally to the obtained materials depending on the annual production. For the rest of the elements under analysis of inventory, $3.18 \%$ was assigned to the mixed RA according to the obtained annual production.

Table (7) shows energy the consumption of different processes of recycling plant.

Table 7. Energy consumption of each process.

\begin{tabular}{|c|c|c|}
\hline \multirow{2}{*}{ Process } & Diesel oil (l) & $\mathbf{k}$ Energy Consumption \\
\cline { 2 - 3 } & $100 \%$ screening & - \\
\hline 1 & $52.41 \%$ (diesel screening) & $33.94 \%$ (electrical screening) \\
\hline 2 & - & $35.24 \%$ (electrical screening) \\
\hline 3 & & $53.35 \%$ (trommel) \\
\hline & $12.03 \%$ (diesel screening) & $7.80 \%$ (electrical screening) \\
\hline 4 & $47.59 \%$ (diesel screening) & $25.29 \%$ (mill) \\
\hline & & $23.02 \%$ (electrical screening) \\
\hline & $74.40 \%$ (diesel screening) & $34.85 \%$ (trommel) \\
\hline 5 & & $74.70 \%$ (mill) \\
\hline
\end{tabular}

The analysis of life cycle inventory studies, all the energy recourses used for ceramic RA fabrication, as well as the consumption of different products derived from this activity. All the data is referred to the functional unit and all the calculations were drawn from the meeting with managers of the company TEC-REC. (Table 8) shows this life cycle inventory data. 
Table 8. Inventory and calculation of carbon footprint.

\begin{tabular}{|c|c|c|c|c|}
\hline Element & \% Ceramic aggregate & Unit & Emission factor & kgCO.eq \\
\hline Air conditioning R-410 & 0.064 & $\mathrm{~kg}$ & $675 \mathrm{kgCO}_{2} / \mathrm{kg}$ & 43.2 \\
\hline Air conditioning R-22 & 0.064 & $\mathrm{~kg}$ & $1840 \mathrm{kgCO}_{2} / \mathrm{kg}$ & 117.76 \\
\hline Air conditioning R-410 & 0.064 & $\mathrm{~kg}$ & $675 \mathrm{kgCO}_{2} / \mathrm{kg}$ & 43.2 \\
\hline Printer toner & 0.064 & $\mathrm{~kg}$ & $0.712 \mathrm{kgCO}_{2} / \mathrm{kg}$ & 0.046 \\
\hline Handled paper & 6.996 & $\mathrm{~kg}$ & $1.2 \mathrm{kgCO}_{2} / \mathrm{kg}$ & 8.395 \\
\hline Oil and fuel filters & 4.770 & $\mathrm{~kg}$ & $0.712 \mathrm{kgCO}_{2} / \mathrm{kg}$ & 3.396 \\
\hline Oil & 19.398 & $\mathrm{~kg}$ & $1.045 \mathrm{kgCO}_{2} / \mathrm{kg}$ & 20.271 \\
\hline Batteries & 1.463 & $\mathrm{UI}$ & $0.712 \mathrm{kgCO}_{2} / \mathrm{kg}$ & 1.042 \\
\hline Plastic containers & 0.636 & $\mathrm{~kg}$ & $0.712 \mathrm{kgCO}_{2} / \mathrm{kg}$ & 0.453 \\
\hline Aerosols & 0.541 & $\mathrm{~kg}$ & $0.712 \mathrm{kgCO}_{2} / \mathrm{kg}$ & 0.386 \\
\hline Batteries(2) & 0.064 & $\mathrm{~kg}$ & $0.712 \mathrm{kgCO}_{2} / \mathrm{kg}$ & 0.046 \\
\hline Electrical energy & 4596 & $\mathrm{kWh}$ & $0.36 \mathrm{kgCO}_{2} / \mathrm{kWh}$ & $1.654,56$ \\
\hline Paper & 1.361 & $\mathrm{~kg}$ & $1.2 \mathrm{kgCO}_{2} / \mathrm{kg}$ & 1.633 \\
\hline Used oil & 11.766 & $\mathrm{~kg}$ & $0.712 \mathrm{kgCO}_{2} / \mathrm{kg}$ & 8.377 \\
\hline Fuel & 569 & $\mathrm{~kg}$ & $0.382 \mathrm{kgCO}_{2} / \mathrm{kg}$ & 217.358 \\
\hline Mobile combustion & 1057 & 1 & $2.471 \mathrm{kgCO}_{2} / 1$ & $2.611,85$ \\
\hline Grease & 0.73 & $\mathrm{~kg}$ & $0.712 \mathrm{kgCO}_{2} / \mathrm{kg}$ & 0.519 \\
\hline Fuel transport & $0.569 \mathrm{x} 50$ & $0.072 \mathrm{kgCO}_{2} / \mathrm{T}^{\mathrm{kgm}}$ & 2.048 \\
\hline & & $\mathrm{Total}$ & $4.734,15$ \\
\hline
\end{tabular}

Once the quantity of $\mathrm{kgC}_{\mathrm{O} 2}$.eq produced by ceramic recycled aggregates fabrication is obtained, this value is divided by the quantity of this fabricated material obtained in a way that the value of carbon footprint is of 0.001336 $\mathrm{kgC}_{\mathrm{O} 2}$.eq/kg. Comparing this value with natural aggregate carbon footprint: $0.0181 \mathrm{kgC}_{\mathrm{O} 2}$.eq [18], it can be concluded that environmental impact of recycled aggregates is significantly lower than that derived from the exploitation of natural aggregates.

\section{CONCLUSION}

Experimental study carried out in this research leads to the following conclusions:

1. Particle size distribution curve of RA is continuous and suitable for masonry mortar fabrication.

2. Main phases obtained in the X-ray diffractogram are quartz and calcite. Other founded phases show low crystalline behavior.

3. In terms of characterization, there are no significant differences between ceramic RA and concrete RA. Nevertheless, recycled mortars fabricated with concrete recycled aggregates show better results in the carried out tests.

4. Real density of recycled mortar is lower compared to mortar elaborated using natural sand as a result of lower density of RA. It causes a slight decrease in building permanent loads.

5. Generally, recycled mortar shows poorer mechanical behavior compared to the reference mortar. Shrinkage is one of the most affected properties. Nevertheless, recycled mortar complies with all the standard requirements taken as a reference.

6. Carbon footprint of recycled aggregates fabrication is significantly lower than that of natural aggregate fabrication. As a result, the use of this type of aggregate reduces $\mathrm{C}_{02}$ emissions and contributes in the development of more sustainable construction.

7. As a final conclusion, it can be stated that masonry mortar fabricated using CEM IV with 1:3 or 1:4 compounds proportion can incorporate $100 \%$ of two types of RA complying with the requirement established by the Spanish standards.

\section{STANDARDS USED IN THE RESEARCH}

- UNE-EN 197-1. Cement. Composition, specifications and conformity criteria for common cements.

- UNE-EN 933-1:2012. Tests for geometrical properties of aggregates - Part 1: Determination of particle size 
distribution - Sieving method.

- UNE-EN 933-2:1995. Test for geometrical properties of aggregates - Part 2: Determination of particle size distribution. Test sieves, nominal size of apertures.

- UNE-EN 998-1:2010. Specification for mortar for masonry - Part 1: Rendering and plastering mortar.

- UNE-EN 1015-2:1998. Methods of test for mortar for masonry - Part 2: Bulk sampling of mortars and preparation of test mortars.

- UNE-EN 1015-3:1999. Methods of test for mortar for masonry. Determination of consistence of fresh mortar (by flow table).

- UNE-EN 1015-10:1999. Methods of test for mortar for masonry - Part 10: Determination of dry bulk density of hardened mortar.

- UNE-EN 1015-11:1999. Methods of test for mortar for masonry - Part 11: Determination of flexural and compressive strength of hardened mortar.

- UNE-EN 1015-18:2002. Methods of test for mortar for masonry - Part 18: Determination of water absorption coefficient due to capillary action of hardened mortar.

- UNE-EN 1015-19:1999. Methods of test for mortar for masonry. Determination of water vapour permeability of hardened rendering and plastering mortars.

- UNE-EN 1097-3:1998. Tests for mechanical and physical properties of aggregates - Part 3: Determination of loose bulk density and voids.

- UNE-EN 1097-6:2001. Tests for mechanical and physical properties of aggregates - Part 6: Determination of particle density and water absorption.

- UNE-EN 14040:2006. Environmental management. Life cycle assessment. Principles and framework

- UNE-EN 15804:2013. Sustainability of construction works. Environmental product declarations. Core rules for the product category of construction products

- UNE-EN 13139:2002. Aggregates for mortar.

\section{ETHICS APPROVAL AND CONSENT TO PARTICIPATE}

Not applicable.

\section{CONSENT FOR PUBLICATION}

Not applicable.

\section{CONFLICT OF INTEREST}

The authors declare no conflict of interest, financial or otherwise.

\section{ACKNOWLEDGEMENTS}

The authors gratefully acknowledge the support of the Architectural Construction and Control Department's laboratory of the Technical University School of Architecture (Madrid Polytechnic University) and the Chemistry and Polymers Department's laboratory of the University School of Technical Industrial Engineering (Universidad Politecnica de Madrid, España) and the TEMA Research Group. The authors are also grateful to the BASF Construction Chemicals Spain S.L. for their technical support. The authors would like to show their gratitude to the recycling plants "El Molar" and "TEC-REC" for their collaboration in the research development.

\section{REFERENCES}

[1] European Commission, Eurostat statistics for waste flow generation. 2013 http://epp.eurostat.ec.europe.eu/ portal/page/portal/ eurostat/homel.

[2] P. Villoria, M. del Río, C. Porras, and A. de San Antonio, "European legislation and implementation measures in the management of construction and demolition waste", Open Constr. Build. Technol. J., vol. 5, suppl. (Suppl. 2-M6), pp. 156e-161, 2011. [http://dx.doi.org/10.2174/1874836801105010156]

[3] Royal Decree 105/2008 of 1 February, which regulates the production and management of construction and demolition waste. Ministry of the Presidency BOE-A-2008-2486 (The Official Spanish State Gazette)., .

[4] M. Sánchez de Juan, "Research of the use of recycled aggregates in structural concrete fabrication", Doctoral Thesis. E.T.S.I. Roads, Canals and Ports., Technical University of Madrid, 2004. 
[5] Spanish Ministry of Public Works, "Instrucción de Hormigón Estructural EHE-08 (Spanish Structural Concrete Code)", BOE, vol. 203, pp. 258-266, 2008

[6] Proyecto Gear, Guía española de áridos reciclados procedentes de Residuos de Construcción y Demolición (RCD). Fueyo editores, ISBN 978-84-939391-2-0., 2012.

[7] M. Etxeberria, E. Vázquez, A. Marí, and M. Barra, "Influence of Amount of Recycled Coarse Aggregates and Production Process on Properties of Recycled Aggregate Concrete", Cement Concr. Res., vol. 37, pp. 735-742, 2007.

[http://dx.doi.org/10.1016/j.cemconres.2007.02.002]

[8] F. Debieb, L. Courard, S. Kenai, and R. Degeimbre, "Roller Compacted Concrete with Contaminated Recycled Aggregates", Constr. Build. Mater., vol. 23, pp. 3382-3387, 2009.

[http://dx.doi.org/10.1016/j.conbuildmat.2009.06.031]

[9] T-Y. Tu, Y-Y. Chen, and C-L. Hwang, "Properties of HPC with recycled aggregates", Cement Concr. Res., vol. 36, pp. 943-950, 2006. [http://dx.doi.org/10.1016/j.cemconres.2005.11.022]

[10] M.S. de Juan, and P.A. Gutierrez, "Study on the influence of attached mortar content on the properties of recycled concrete aggregate", Constr. Build. Mater., vol. 23, pp. 872-877, 2009.

[http://dx.doi.org/10.1016/j.conbuildmat.2008.04.012]

[11] B.E. Marmash, and K.S. Elliot, "The properties of recycled precast concrete hollow core slabs for use as replacement aggregate in concrete", Waste Management Series, vol. 1, pp. 769-781, 2000. [http://dx.doi.org/10.1016/S0713-2743(00)80087-2]

[12] S. Nagataki, A. Gokce, and T. Saeki, "Effects of recycled aggregate characteristics on performance parameters of recycled aggregate concrete", In: Fifth Canmet/ACI International Conference of Durability of Concrete, Barcelona, 2000.

[13] V.W. Tam, K. Wang, and C.M. Tam, "Assessing relationships among properties of demolished concrete, recycled aggregate and recycled aggregate concrete using regression analysis", J. Hazard. Mater., vol. 152, no. 2, pp. 703-714, 2008. [http://dx.doi.org/10.1016/j.jhazmat.2007.07.061] [PMID: 17764837]

[14] S.T. Lee, "Influence of recycled fine aggregates on the resistance of mortars to magnesium sulfate attack", Waste Manag., vol. 29, no. 8, pp. 2385-2391, 2009. [http://dx.doi.org/10.1016/j.wasman.2009.04.002] [PMID: 19467853]

[15] J. Silva, J. De Brito, and R. Veiga, "Recycled red-clay ceramic construction and demolition waste for masonry mortars productions", Materials in Civil Engineering., vol. 22, pp. 236-244, 2010. [http://dx.doi.org/10.1061/(ASCE)0899-1561(2010)22:3(236)]

[16] M. Braga, J. De Brito, and R. Veiga, "Incorporation of fine concrete aggregates in mortars", Constr. Build. Mater., vol. 36, pp. 960-968, 2012. [http://dx.doi.org/10.1016/j.conbuildmat.2012.06.031]

[17] E. Fernandez, J.R. Jimenez, J. Ayuso, J.M. Fernandez, and J. de Brito, "Maximum feasible use of recycled sand from construction and demolition waste for ecomortar production e part-I: ceramic masonry waste", J. Clean. Prod., vol. 87, pp. 692e-706, 2015.

[18] Available at: http://www.ecoinvent.org/

(C) 2017 Cortina et al.

This is an open access article distributed under the terms of the Creative Commons Attribution 4.0 International Public License (CC-BY 4.0), a copy of which is available at: https://creativecommons.org/licenses/by/4.0/legalcode. This license permits unrestricted use, distribution, and reproduction in any medium, provided the original author and source are credited. 